\title{
ТЕОРЕТИКО-ПРАВОВИЙ АНАЛІЗ ПРАВ ОСІБ 3 ІНВАЛІДНІСТЮ ТА МІСЦЯ В ЇХ СИСТЕМІ ПРАВА НА ДОСТУПНІСТЬ ОБ' 'КТІВ І ПОСЛУГ
}

\author{
ВАРГУЛЯК Олена Геннадіївна - студентка 2 курсу Дніпропетровського \\ університету митної справи та фінансів
}

DOI 10.32782/NP.2021.1.19

Статья посвящена вопросу места права на доступность объектов и услуг в системе прав лии с инвалидностью. С иелью разностороннего раскрылтия задекларированной проблематики автором в подтверждение заключения об актуальности исследуемой темь приведенъ фбактические даннъие о влиянии существуюших в обществе барьеров на жизнь лии с инвалидностью и других маломобильнъхх групп населения. Также приведен перечень определенных на международном уровне барьеров, связанньх с инвалидностью.

Помимо прочего в статье указано о научных позициях относительно понимания содержания категории «права человека» $и$ их классибикации по ряду признаков. Замечено на возможности применения существующей группировки прав человека относительно прав лич с инвалидностью.

Наконеч автором перечисленъг гарантированъие лицам с инвалидностью права и аргументировано ключевое место права на доступность обтектов и услуг в их системе. Акцентировано на соответствии такого въвода позиции гражданского общества в сфере зашить прав лии с инвалидностью.

Ключевъие слова: человек с инвалидностью, маломобильныле группь населения, права человека, право на доступность объектов и услуг, барьеры, доступная среда.

Постановка проблеми

Сьогодні навіть у найбільш розвинених державах існує безліч різного характеру бар'єрів на шляху до повноцінного жит- тя осіб з інвалідністю на рівні $з$ іншими. Усвідомлюючи рівень негативного впливу недоступності середовища для зазначеної категорії осіб, світова спільнота визнала право осіб з інвалідністю на доступність нарівні з іншими до фізичного оточення, до транспорту, до інформації та зв'язку, зокрема інформаційно-комунікаційних технологій і систем, а також до інших об'єктів і послуг, відкритих або таких, що надаються населенню, як у міських, так і в сільських районах (стаття 9 Конвенції). Більше того, доступність визначено одним із ключових принципів Конвенції Організації Об'єднаних Націй про права осіб з інвалідністю [9].

Зазначене дає підстави стверджувати про значущість для науки і практики питання природи права осіб з інвалідністю на доступність об'єктів і послуг, його місця в системі прав, гарантованих зазначеній категорії людей.

\section{Аналіз останніх досліджень i} публікацій

Фрагментарно питання прав осіб 3 інвалідністю ставало предметом дослідження багатьох науковців, серед яких I.А. Булик, В.М. Кондратенко, В.П. Мельник, С.В. Пасічніченко, В.І. Петрусевич, С.Ю. Соболь, А.М. Соцька, В.С. Тарасенко, А.Л. Терещенко, М.В. Чічкань та ін. Однак всебічному вивченню природи права осіб з інвалідністю на доступність об'єктів і послуг уваги в наукових джерелах не приділено, що зумовлює 
потребу у розкритті задекларованої в назві статті тематики.

Відтак метою статті $є$ 3'ясування місця права на доступність об'єктів і послуг серед прав осіб з інвалідністю.

\section{Виклад основного матеріалу}

Значущість права осіб з інвалідністю на доступність об’єктів і послуг легко підтвердити фактичними даними. Зокрема, згідно з оцінками експертів Всесвітньої організації охорони здоров'я: 1) нині у світі в однієї 3 десяти осіб є одне або кілька функціональних порушень, які стають причиною інвалідності; 2) $35 \%$ осіб у віці 60 років мають стійкі функціональні порушення, які перешкоджають їм здійснювати звичайні соціальні функції на рівні з іншими; 3) у віці 70 років цей показник зростає до $50 \%$, а у 80 років їх мають $100 \%$ осіб. 3 урахуванням глобальних світових тенденцій старіння населення очікується, що кількість осіб віком 60 років і старших постійно зростатиме. За прогнозами, чисельність людей пенсійного віку з 675 млн у 2005 році сягне 1,9 млрд у 2050 році. Передбачається, що масштаби поширення різних видів та ступенів функціональних порушень серед цієї групи населення також зростуть. Серед загальної чисельності населення маломобільні групи населення становлять: 1) особи з інвалідністю - 10-15\%; 2) особи з тимчасовими порушеннями здоров' я - 1,5 \%; 3) вагітні жінки - майже $1 \%$; 4) особи похилого віку (пенсіонери) - 30-40\%; 5) батьки з дитячими колясками - майже $1 \%$; 5) у більшості країн Европи до цієї групи належать діти дошкільного віку; в Україні їх нараховується понад 2 мільйони [1, с. 20, 22]

Кожна людина, яка належить до згаданих вище категорій, постійно стикається із незліченною кількістю бар'єрів, серед яких бідність, необізнаність суспільства з питання інвалідності, бар'єрність приміщень, транспорту, інформації тощо.

У Всесвітній доповіді щодо інвалідності [4] визначено такі основні бар'єри в суспільстві, пов' язані з інвалідністю:

1) під час розробки політики не завжди враховуються потреби осіб 3 інвалідністю або не вживаються заходи політики і стандарти;

2) особи з інвалідністю значно вразливіші перед дефіцитом таких послуг, як медико-санітарне обслуговування, реабілітація, а також підтримка і допомога;

3) слабка координація послуг, недостатнє кадрове забезпечення та низький рівень професійної підготовки персоналу можуть позначитись на якості, доступності та адекватності послуг для осіб з інвалідністю;

4) ресурси, що виділяються на здійснення заходів політики та планів, часто недостатні;

5) багато будинків (зокрема місця загального користування), транспортні системи й інформація не є доступними для всіх;

6) мало інформації в доступних форматах, тому не задовольняється багато потреб осіб з інвалідністю в галузі комунікації;

7) більшість осіб з інвалідністю не беруть участі у прийнятті рішень з питань, що безпосередньо стосуються їхнього життя;

8) нестача точних, достовірних і порівняльних даних про інвалідність, а також досвіду здійснення ефективних програм, може перешкоджати розумінню проблем і практичним діям [4; 13 , с. 64$]$.

3 огляду на зазначене вище, цілком реалістичним вбачаємо твердження представників громадянського суспільства стосовно того, що забезпечення «доступності» має вирішальне значення, оскільки безпосередньо впливає на користування особами з інвалідністю та іншими маломобільними групами населення всім спектром прав людини; відіграє ключову роль у створенні інклюзивного суспільства, е якому люди з інвалідністю зможуть брати участь у повсякденному житті $[1$, с. 24].

Звідси випливає цілком обгрунтований i беззаперечний висновок стосовно системності прав осіб з інвалідністю, оскільки відповідні права є взаємопов'язаними та взаємозалежними, ефективність та результативність реалізації того чи іншого права безпосередньо залежить від рівня та якості реалізації інших прав.

Крім того, вищезазначене свідчить на користь висновку про ключове місце права на доступність об’єктів і послуг у житті осіб 3 
інвалідністю, а також інших маломобільних груп населення, рівень забезпеченості якого в нашій державі є вкрай низьким, у чому можна переконатися, навіть не виходячи 3 дому, а ставлячи питання про ширину дверей у квартирі, наявність порогів, безпечність ванної кімнати, висоту робочої поверхні на кухні, наявність літератури шрифтом Брайля тощо.

Загалом інститут права людини є складним та динамічним. Ще більш складним вважаємо інститут права осіб 3 інвалідністю через особливий правовий статус таких людей, зумовлений наявністю в них інвалідності. Одним із ключових прав осіб з інвалідністю, на наше переконання, є право на доступність об'єктів і послуг як своєрідна гарантія реалізації цими людьми усього масиву гарантованих їм прав. Справедливість зазначеної позиції спробуємо довести шляхом 3'ясування місця права на доступність об'єктів і послуг у системі прав осіб з інвалідністю.

Загальноприйнято вважати права людини певними ії можливостями, необхідними для існування та розвитку у конкретно-історичних умовах, які об'єктивно зумовлюються досягнутим рівнем розвитку людства і мають бути загальними та рівними для всіх людей [19, с. 16].

Оскільки права людини передбачають ставлення до кожного як до носія таких прав, то вони забезпечують сприйняття іншого суб'єкта відносин як рівного [12, с. 218].Особливо актуальною така позиція є у випадку 3 особами 3 інвалідністю, які на сьогодні зазнають найбільшої дискримінації 3 боку соціуму.

Масив прав людини є надзвичайно великим. Вони закріплюються і на міжнародноправовому рівні, і на конституційному рівні окремих держав, і у внутрішньодержавних нормативно-правових актах.

Сьогодні в науковій літературі зустрічаються класифікації прав людини за значним масивом ознак, серед яких, у тому числі, такі:

1) за соціальним призначенням з урахуванням сфер життєдіяльності людини: а) політичні, соціально-економічні, громадянські (особисті) і культурні [14, с. 272-273]; б) гро- мадянські, політичні, економічні, соціальні, культурні та екологічні права [22, с. 39];

2) залежно від правового забезпечення: конституційні (основні); закріплені в законодавстві (галузеві). При цьому конституційні права складають юридичне підгрунтя для прав галузевих і мають відносно них вищу юридичну силу [20, с. 117-121];

3) за підпорядкованістю: основні і похідні. Перші - найбільш загальні права людини і громадянина, які закладають основу правового статусу особистості. Зафіксовані в конституціях держав і міжнародно-правових актах, вони є правовою базою для похідних прав. Другі - права і свободи, тією чи іншою мірою похідні від основних прав і свобод, які доповнюють, розвивають і конкретизують основні права [3, с. 7];

4) за характером потреб людини, які забезпечуються правами: фізичні права (на життя; фізичну недоторканність; вибір місця проживання; безпечне природне середовище; житло; належний рівень матеріального забезпечення; власність на предмети споживання; медичне обслуговування та інші види соціального захисту тощо); особистісні права (на ім'я; честь і гідність; свободу сумління, переконань та їх прояву й поширення тощо); культурні (гуманітарні) (на освіту й виховання; користування надбаннями культури і мистецтва; наукову, технічну і художню творчість; авторські права тощо); економічні (на власність щодо засобів виробництва; здобуття професії; вибір та здійснення трудової або іншої діяльності; сприятливі умови та справедливу оплату праці; відпочинок і дозвілля); політичні права (на громадянство та правосуб'єктність; участь у формуванні представницьких органів державної влади та місцевого самоврядування; участь у державному управлінні суспільством; участь у створенні й діяльності громадських об'єднань; державний захист від порушень прав і свобод людини тощо) [18, c. 12; 9];

5) за аспектом свободи: позитивні та негативні. Негативні права містяться у праві особи на захист від будь-якого втручання, у тому числі державного, у здійснення громадянських прав і політичних прав. Ці права захищають особу від небажаних, таких, 
які порушують їі свободу, втручань чи обмежень. Реалізація негативних прав не залежить від державних ресурсів, соціальноекономічного розвитку країни. Позитивні права фіксують права особи на покращення свого становища і зростання культурного статусу, що забезпечується державою. Обов'язком держави є створення умов для реалізації громадянами своїх позитивних прав [2, с. 26-27];

6) залежно від функціонального призначення: матеріальні та процесуальні.

Наведена вище класифікація стосується повною мірою і прав осіб з інвалідністю як осіб з особливим правовим статусом, який зумовлює наділення цієї категорії людей певним обсягом спеціальних прав.

Права осіб з інвалідністю В.М. Кондратенко пропонує розуміти як сукупність природних прав людини, закріплених у міжнародних правових актах, і конституційних правових можливостей громадян, що визначають вид і міру поведінки індивіда у суспільстві, а також гарантований державою достатній та доступний обсяг суспільних благ і спеціальних соціальних умов для його вільного існування та розвитку з урахуванням характеру стійких порушень функцій організму [10, с. 43].

Відповідні права передбачено міжнародними та національними законодавчими актами, серед яких ключовими варто визначити Конвенцію ООН про права осіб з інвалідністю [9], Европейську соціальну хартію (переглянуту) [5], Свропейський кодекс соціального забезпечення [6], Загальну декларацію прав людини [7], Пакт про економічні, соціальні і культурні права [15], закони України «Про основи соціальної захищеності осіб з інвалідністю в Україні»[16], «Про реабілітацію осіб з інвалідністю в Україні» [17] тощо.

Конвенція ООН про права осіб з інвалідністю [9] гарантує цій категорії людей такі права: на рівність і недискримінацію (стаття 5); на доступність (стаття 9); на життя (стаття 10); на забезпечення захисту й безпеки у ситуаціях ризику та надзвичайних гуманітарних ситуаціях (стаття 11); на рівність перед законом (стаття 12); на доступ до правосуддя (стаття 13); на свободу та особисту не- доторканість (стаття 14); на свободу від катувань і жорстоких, нелюдських або таких, що принижують гідність, видів поводження та покарання (стаття 15); на свободу від експлуатації, насилля та наруги (стаття 16); на захист особистої цілісності (стаття 17); на свободу пересування та громадянство (стаття 18); на самостійний спосіб життя й залучення до місцевої спільноти (стаття 19); на індивідуальну мобільність (стаття 20); на свободу висловлення думки та переконань і доступ до інформації (стаття 21); на недоторканість приватного життя (стаття 22); на повагу до дому та сім’ї (стаття 23); на освіту (стаття 24); на здоров'я (стаття 25); на працю та зайнятість (стаття 27); на достатній життєвий рівень та соціальний захист (стаття 28); на участь у політичному та суспільному житті (стаття 29); на участь у культурному житті, проведенні дозвілля й відпочинку та заняттях спортом (стаття 30).

Фактично всі закріплені в національному законодавстві права осіб з інвалідністю відповідають вищезазначеному переліку прав.

При цьому варто пам'ятати, що суб'єктивні юридичні права - динамічні, вони постійно виникають, змінюються та припиняються, їх загальну кількість охопити практично неможливо, адже мільйони суб'єктів можуть мати права (обов'язки), які грунтуються на одній нормі, а в кожного суб'єкта права - комплекс різних прав (політичних, економічних, культурних, екологічних тощо) [11]. «Humani iuris condicio semper in infinitum decurrit et nihil est in ea, quod stare perpetuo possit» - правове становище людей постійно та нескінченно змінюється, і немає в ньому нічого незмінного [21, с. 229]. Тому наведений нами перелік прав осіб з інвалідністю не є вичерпним.

На нашу думку, з перелічених прав ключовим є право на доступність об'єктів і послуг, оскільки саме доступність гарантує особам 3 інвалідністю можливість реалізувати інші права та свободи. Отже, право на доступність об'єктів і послуг є своєрідною гарантією реалізації всього масиву гарантованих особам з інвалідністю прав.

У розмінні Конвенції ООН про права осіб 3 інвалідністю зміст доступності полягає у тому, щоб надати особам з інвалід- 
ністю можливість вести незалежний спосіб життя й усебічно брати участь у всіх аспектах життя, держави-учасниці вживають належних заходів для забезпечення особам 3 інвалідністю доступу нарівні 3 іншими до фізичного оточення, до транспорту, до інформації та зв’язку, зокрема інформаційнокомунікаційних технологій і систем, а також до інших об'єктів і послуг, відкритих або таких, що надаються населенню як у міських, так і в сільських районах. Ці заходи, які включають виявлення й усунення перепон і бар'єрів, що перешкоджають доступності, повинні поширюватися, зокрема: а) на будинки, дороги, транспорт й інші внутрішні та зовнішні об'єкти, зокрема школи, житлові будинки, медичні установи та робочі місця; b) на інформаційні, комунікаційні та інші служби, зокрема електронні служби та екстрені служби (стаття 9) [9].

Висновки. Резюмуючи, зазначимо на цілком слушному зауваженні громадських об'єднань, які опікуються питаннями інвалідності: «з прийняттям Конвенції ООН про права осіб з інвалідністю було прийнято єдиний підхід і визнано, що інвалідність - це результат взаємодії між людьми, що мають фізичні, розумові, інтелектуальні чи сенсорні порушення та перешкодами у стосунках та середовищі, які знижують соціальну активність особи. Таким чином, вирішення проблем інвалідності потрібно шукати у створенні доступного середовища для всіх людей» [1, с. 5, 24].

\section{література}

1. Азін В.О., Байда А.Ю., Грибальський Я.В., Красюкова-Еннс О.В. Доступність та універсальний дизайн : навч.-метод. посіб. К, 2013. 128 с.

2. Бисага Ю.М., Палінчак М.М., Белов Д.М., Данканич М.М. Права людини Ужгород, 2003. 189 с.

3. Волинка К.Г. Правовий статус особи та гарантії реалізації прав і свобод за Конституцією України. К.: РННУ Діні, 1998. $35 \mathrm{c.}$

4. Всесвітня доповідь про інвалідність (2011 p.). URL: http://www.who.int/disabilities/ world_report/2011/report/ru.
5. Европейська соціальна хартія (переглянута) від 3 трав. 1996 р. URL: https:// zakon.rada.gov.ua/go/994_062.

6. Европейський кодекс соціального забезпечення від 16 квіт. 1964 p. URL: https:// zakon.rada.gov.ua/laws/show/994_329\#Text.

7. Загальна декларація прав людини від 10 груд. 1948 р. URL: https://zakon.rada.gov. ua/go/995_015.

8. Кожан В.В. Особисті права та свободи людини: Загальнотеоретичне дослідження: дис. ... канд. юрид. наук: 12.00.01. Аьвів, 2016. 229 с.

9. Конвенція ООН про права осіб 3 інвалідністю від 13 груд. 2006 р. URL: https:// zakon.rada.gov.ua/go/995_g71.

10. Кондратенко В.М. Адміністративноправові засоби забезпечення прав і свобод осіб з інвалідністю: дис. ... д-ра юрид. наук: 12.00.07. Х., 2019. 449 с.

11. Мацькевич М.М. Генеза прав людини: правовий та філософський аспекти. $H a$ уковий вісник Аввівсъкого державного університету внутрішніх справ. серія горидина, 2014. Вип. 4. С. 54-66. URL: http://nbuv.gov.ua/ UJRN/Nvlduvs_2014_4_9.

12. Мацькевич М.M. Конституційно-правові засади забезпечення культурних прав і свобод людини та громадянина в Україні: монографія. Івано-Франківськ: Місто НВ, 2012. 464 c.

13. Мельник В.П. Міжнародно-правове регулювання соціального захисту осіб 3 інвалідністю у сфері реабілітації та праці: теоретико-правовий підхід. Прикарпатський юридичний вісник. 2018. Вип. 1(22). С. 63-67.

14. Общая теория государства и права: Академический курс. Т. 1. М.: Изд-во «Зерцало», 1998. 416 с.

15. Пакт про економічні, соціальні і культурні права від 16 груд. 1966 р. URL: https:// zakon.rada.gov.ua/laws/show/995_042\#Text.

16. Про основи соціальної захищеності осіб з інвалідністю в Україні : Закон України від 21 берез. 1991 р. № 875-XII. URL:https:// zakon.rada.gov.ua/go/875-12.

17. Про реабілітацію осіб з інвалідністю в Україні: Закон України від 6 жовт. 2005 p. № 2961-IV. URL: https://zakon.rada.gov.ua/ go/2961-15. 


\section{Цивільне, підприсмницьке, господарське та трудове право}

\begin{tabular}{|c|}
\hline 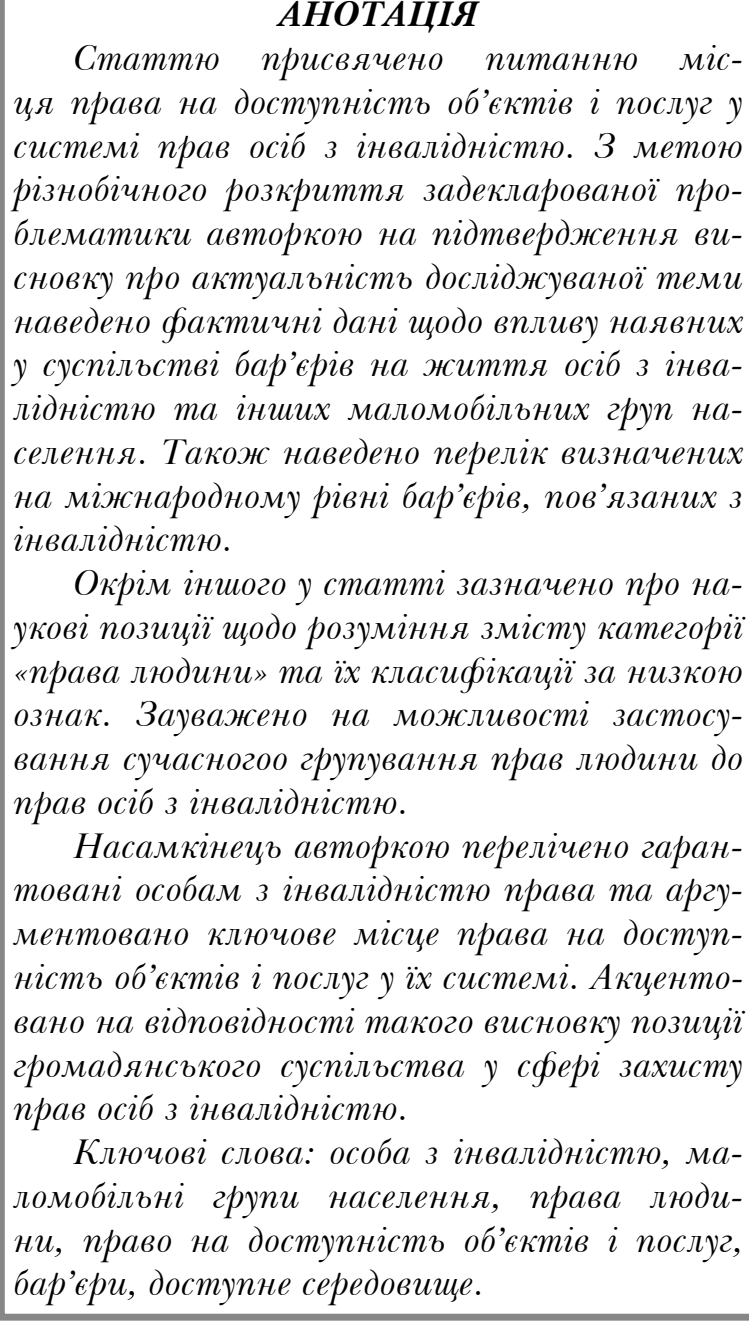 \\
\hline
\end{tabular}

18. Рабінович П.М. Основи загальної теорії права та держави. К.: Атіка, 2001. 176 с.

19. Рабінович П.М. Основні права людини: поняття, класифікації, тенденції. I Укp. иасопис прав людини. 1995. № 1. С. 14-22.
The article is devoted to the question of the place of the right to accessibility of objects and services in the system of rights of persons with disabilities. In order to comprehensively disclose the declared issues, the author provides factual data on the impact of existing barriers in society on the lives of people with disabilities and other low-mobility groups to confirm the conclusion about the relevance of the research topic. There is also a list of internationally identified barriers related to disability.

Among other things, the article mentions scientific positions on understanding the content of the category of «human rights» and their classification on a number of grounds. The possibilities of applying the existing grouping of human rights to the rights of persons with disabilities are noted.

Finally, the author lists the rights guaranteed to persons with disabilities and argues the key place of the right to access facilities and services in their system. Emphasis is placed on the conformity of this conclusion to the position of civil society in the field of protection of the rights of persons with disabilities.

Key words: person with disabilities, low mobility groups, human rights, right to access facilities and services, barriers, accessible environment.

20. Рабінович П.М. Хавронюк М.І. Права людини і громадянина: навч. посіб. К.: Атіка, 2004. 250 с.

21. Хоміцька 3.М. Словник латинських юридичних висловів. Х.: Право, 2008. 272 с.

22. Шумак I.О. Громадянські права і свободи людини за Конституцією України: дис. ... канд. юрид. наук: 12.00.02. К., 2000. 193 с. 